\title{
Early stimulation in the development of children with microcephaly: maternal perception
}

\author{
Estimulação precoce diante do desenvolvimento da criança com microcefalia: percepção materna \\ Estimulación precoz en el desarrollo del niño con microcefalia: percepción materna
}

\section{Brena Shellem Bessa de Oliveira' ORCID: 0000-0001-6142-1421 \\ Francisca Mayra de Sousa Melo' ORCID: 0000-0002-9622-7669 \\ Rhaiany Kelly Lopes de Oliveira' ORCID: 0000-0002-5404-2287}

Joana Furtado de Figueiredo Neta" ORCID: 0000-0002-5246-921X

Flávia Paula Magalhães Monteiro' ORCID: 0000-0001-9401-2376

Emanuella Silva Joventino' ORCID: 0000-0001-9786-5059

'Universidade da Integração Internacional da Lusofonia Afro-Brasileira. Redenção, Ceará, Brazil. "Policlínica Doutor Clovis Amora Vasconcelos. Aracoiaba, Ceará, Brazil.

How to cite this article: Oliveira BSB, Melo FMS, Oliveira RKL, Figueiredo Neta JF, Monteiro FPM, Joventino ES. Early stimulation in the development of children with microcephaly: maternal perception. Rev Bras Enferm. 2019;72(Suppl 3):139-46. doi: http://dx.doi.org/10.1590/0034-7167-2018-0272

Corresponding Author: Brena Shellem Bessa de Oliveira E-mail: brennashellem@gmail.com

Submission: 04-30-2018 Approval: 06-16-2018

\section{ABSTRACT}

Objective: To know the maternal perception about early stimulation and its repercussion in the development of the child with microcephaly associated with zika virus. Method: A qualitative study was carried out from June to August 2017 with five mothers of children diagnosed with microcephaly associated with zika virus. The data were collected through individual interviews with semi-structured script and evaluated by the content analysis, in its thematic modality. Results: Mothers recognized the benefits and the advances in the development of the child after the beginning of the early stimulation. It is noteworthy that the difficulty of transportation was the main reason for the lack of attendance at consultations, and that the short time of stimulation was the main weakness of the service. Final considerations: The recognition of maternal perception and the difficulties and weaknesses of the service can contribute to the elaboration of public policies and the planning of holistic care for children with microcephaly and their families.

Descriptors: Microcephaly; Child Development; Child Health; Zika Virus; Pediatric Nursing.

\section{RESUMO}

Objetivo: Conhecer a percepção materna acerca da estimulação precoce e sua repercussão no desenvolvimento da criança com microcefalia associada ao zika vírus. Método: Estudo qualitativo, realizado de junho a agosto de 2017 com cinco mães de crianças diagnosticadas com microcefalia associada ao zika vírus. Os dados foram coletados por meio de entrevistas individuais com roteiro semiestruturado e avaliados pela análise de conteúdo, em sua modalidade temática. Resultados: Verificou-se que as mães reconheceram os benefícios e os avanços no desenvolvimento da criança após o início da estimulação precoce. Ressalta-se que a dificuldade de transporte foi o principal motivo para a falta de assiduidade nas consultas, e que o curto tempo de estimulação consistiu na principal fragilidade do serviço. Considerações finais: $O$ reconhecimento da percepção materna e das dificuldades e fragilidades do serviço podem contribuir na elaboração de políticas públicas e no planejamento da assistência holística à criança com microcefalia e sua família.

Descritores: Microcefalia; Desenvolvimento Infantil; Saúde da Criança; Zika Vírus; Enfermagem Pediátrica.

\section{RESUMEN}

Objetivo: Conocer la percepción materna acerca de la estimulación precozy su repercusión en el desarrollo del niño con microcefalia asociada al zika virus. Método: Estudio cualitativo, realizado de junio a agosto de 2017 con cinco madres de niños diagnosticados con microcefalia asociada al zika virus. Los datos fueron recolectados por medio de entrevistas individuales con guion semiestructurado y evaluados por el análisis de contenido, en su modalidad temática. Resultados: Se verificó que las madres reconocieron los beneficios y los avances en el desarrollo del niño después del inicio de la estimulación precoz. Se resalta que la dificultad de transporte fue el principal motivo para la falta de asiduidad en las consultas, y que el corto tiempo de estimulación consistió en la principal fragilidad del servicio. Consideraciones finales: El reconocimiento de la percepción materna y de las dificultades y fragilidades del servicio pueden contribuir en la elaboración de políticas públicas y en la planificación de la asistencia holística al niño con microcefalia y su familia. Descriptores: Microcefalia; Desarrollo Infantil; Salud del Niño; Virus Zika; Enfermería Pediátrica. 


\section{INTRODUCTION}

Microcephaly is a disorder in which the child's brain develops inadequately, resulting in lower cephalic perimeter than expected for age, gender, and race ${ }^{(1)}$. This malformation may have congenital or postnatal etiology and may be caused by infections during pregnancy, by the use of teratogenic substances during the gestational period, or by genetic and environmental causes ${ }^{(2)}$.

Among the micro-organisms that can cause microcephaly, the zika virus, a flavivirus first isolated in 1947 in a feverish Rhesus monkey caged in the Zika forest, located in Uganda, Africa ${ }^{(3)}$, is currently prominent.

The hypothesis of a cause and effect relationship between zika virus and microcephaly was first described in Brazil, when it was noticed an exacerbated growth in the number of Brazilian children with this disease and changes in the central nervous system (CNS), concomitant to the occurrence of a disease caused by the virus. In addition, cytomegalovirus, toxoplasmosis, and genetic or environmental causes of infection-responsible for causing this type of anomaly ${ }^{(4)}$ - were ruled out in these cases, which reinforced the hypothesis mentioned.

Faced with this scenario, research has been developed and, today, several studies that demonstrate the neurotropism of the virus $^{(5-7)}$, as well as its ability to cross the transplacental barrier and infect the fetus are reported in the literature ${ }^{(8-9)}$. This affinity for the CNS may result in the development of cerebral calcifications, cerebellar hypoplasia and ventriculomegaly, which increases the risk of the child with microcephaly presenting, in an associated way, epilepsy, visual and auditory impairments and retardation in neuropsychomotor development ${ }^{(10-12)}$.

Although there is no specific treatment for this malformation, the child has the right, advocated by the Unified Health System (SUS), to have support and assist in his/her development. Thus, services such as rehabilitation, examinations, diagnosis and access to orthotics and prosthetics at all levels of health care should be made available to the microcephalic child $^{(2)}$.

Considering that, in 2016, the Ministry of Health created the Guidelines for early stimulation: children from zero to 3 years old with delayed neuropsychomotor development due to microcephaly. Early stimulation consists of a program composed of a multiprofessional team, with the participation of a nurse, which aims to promote the follow-up and execution of clinical and therapeutic interventions in a high-risk or with organic diseases child, such as microcephaly, aiming to stimulate their neuropsychomotor and intellectual development ${ }^{(13)}$.

However, for a satisfactory evolution in the clinical picture of the child, it is essential that the participation of parents and other family members in the treatment is encouraged, since it is in the social environment that the child should receive most of the stimuli ${ }^{(14)}$. However, it is known that the diagnosis of congenital malformation brings with it a series of stigmas, fears and feelings, such as rejection, guilt, sadness and despair, since the family faces an opposite reality than the one planned ${ }^{(15)}$.

Mothers are protagonists in this context, since they are the main responsible for the care of the child with neurological dysfunctions $s^{(16)}$. Therefore, it is necessary to carry out studies aimed at knowing the maternal perception about microcephaly, early stimulation, its repercussion on children's neuropsychomotor development and access to services recommended by SUS.

Thus, health professionals, especially nurses, can subsidize their care in order to provide holistic and quality care for both the child with microcephaly and their families.

\section{OBJECTIVE}

To know the maternal perception about the early stimulation and its repercussion in the development of the child with microcephaly associated with zika virus.

\section{METHOD}

\section{Ethical aspects}

Considering the ethical aspects, this study was approved by the Research Ethics Committee of the Universidade da Integração Internacional da Lusofonia Afro-Brasileira (Unilab). The research counted on the Informed Consent form and respected the guidelines and norms of Resolution 466/2012 of the National Health Council of the Ministry of Health. It should be noted that, to guarantee the confidentiality and anonymity of the interviewed mothers, each one was coded with the letter $M$ and the sequential number of interviews (M1, M2 ... M5).

\section{Theoretical and methodological background}

Thematic content analysis was used as reference, which consists in the use of research techniques that make it possible to spread and to valid inferences about a certain subject, using specialized and scientific procedures ${ }^{(17)}$.

\section{Study type}

It was a qualitative, descriptive and exploratory research. The choice of this type of work is because qualitative research allows the researcher to understand events according to the subjects' perception of the study and to approach more closely the episode studied - while the exploratory and descriptive study, besides enabling a deeper understanding of the thematic, makes possible the observation and precise description of facts, phenomena and events that develop in a certain reality.

\section{Study scenario}

The study was carried out in the Early Stimulation Center of a polyclinic located in Maciço de Baturité, in the countryside Ceará, which is a reference in this region for the early stimulation of children with delayed neuropsychomotor development.

\section{Research Participants}

The research was carried out with five mothers of children diagnosed with microcephaly associated with zika virus, which made up the total number of children with this condition, followed during the period of study in the mentioned institution. It was adopted as inclusion criteria to be a mother of a child attended and assisted monthly by the professionals of the Early Stimulation 
Center selected in the study. Mothers with restrictions that made it impossible to understand the instruments applied were excluded.

\section{Data collection and organization}

Data collection took place between June and August 2017 and was performed at the Premature Stimulation Service of the place through semi-structured interviews, recorded on an audio device with consent of the mothers and performed in a reserved place, guaranteeing the privacy of the participants. Interviews lasted an average of 45 minutes.

For this purpose, a semi-structured instrument was used, showing sociodemographic data (age, schooling, family income, number of dwellers) and a script composed of guiding themes, which approached the maternal perception about the repercussion of microcephaly in child development, mothers' knowledge about early stimulation and its effects on the development of the child with microcephaly.

\section{Data analysis}

The analysis of the data from the recorded interviews was done through content analysis, in its thematic modality. Thus, the participants' speeches were transcribed in order to ensure maximum accuracy in the records of the mothers' responses.

Subsequently, the transcribed material went through the following steps: pre-analysis, in which an exhaustive reading was made, to deeper understand it; and exploration of the material and treatment of results, when the distribution of snippets and sentences was made, seeking to identify the sense nuclei by inferences. Then, the analysis of the sense nucleus was carried out seeking thematic categories. After the identification of these categories, the participants' statements were regrouped in the themes to which they were appropriate, being interpreted later.

\section{RESULTS}

Regarding the sociodemographic characterization of the studied mothers, it was observed that the women had an age ranging from 18 to 35 years old, with a mean of 27.55 years ( \pm 7.2 ); most of them had a consensual union ( $n=4 ; 80 \%)$, worked in family agriculture $(n=3 ; 60 \%)$, survived with a per capita income of less than $R \$ 234.25$ ( $n=4 ; 80 \%)$, resided in brick house with plaster, had no flushing toilet $(n=3 ; 60 \%)$ and reported mosquitoes in their residence throughout the year $(n=4 ; 80 \%)$. As for the children, it was observed that most of them had age ranging from 12 to 24 months ( $n=4 ; 80 \%)$ and were girls $(n=3 ; 60 \%)$.

The following four thematic categories emerged from the analysis of participants' speeches: 1) Microcephaly and its interface with child growth and development; 2) Maternal knowledge about early stimulation; 3 ) Early stimulation in the development of the child with microcephaly; and 4) Fragility of the service.

\section{Category 1: Microcephaly and its interface with children's growth and development}

Regarding the child's growth and development, it is well known in the interviewees'speeches that they recognized the delay caused by microcephaly, but believe that, even if it is something that occurs slowly, the child has demonstrated developmental progress:

\begin{abstract}
She is very big, she develops well. [...] If she did not have these convulsions, that's it. [...] She already raises her neck. She rubs herself on the side, then she rolls on the bed. She is not crawling, but she moves. But if I let her lie down with her back on the bed, she doesn't turn around so much. She is quiet. [...] She does not sit, because the neck does not help and she has not walked until now. [...] She eats very slowly, she pours a lot out of the corner of her mouth. (M1)
\end{abstract}

His growth and development is better now; after I brought him to therapy he is improving. (M2)

It took a while for her to walk; not to speak, she says everything right. (M3)

Because of her problem, everything is slow. (M4)

Within the neurological picture, everything is fine. There are delays, which is what we expected because of the micro[cephaly], but it is going well. (M5)

\section{Category 2: Maternal knowledge about the role of early stimulation}

When asked about the definition of early stimulation, it was noticed that, even acknowledging the benefits of this, most mothers had difficulty in conceptualizing it, but related it to something beneficial:

I don't know how to answer it. It's what improves her health. But how to explain early stimulation, I don't know how to explain it. (M1)

I think it's to reanimate the child, to see if they move better. (M2)

I will not say that I understand much, because I don't. Only now I realize that it has been doing good. (M3)

Early stimulation, it is very good because it stimulates the development of the child. (M4)

It's the way to try and help them. It's playing. It's stimulating! (M5)

In addition, it was noticed that the mothers recognized the importance of stimulating the children at home, as they show to seek care to improve the child's development:

If she does not show up here, I do it at home. And so it goes. (M1)

We do it here and at home all the time [...]. It's playing, it's talking, it's singing. (M5)

As for receiving information about ways to stimulate the child at home, it was observed that four women had previously been clarified on this topic-but the only ones responsible for instructing the mothers, according to them, were the professionals who worked at the Early Stimulation Center, where the study was developed. 
Among the activities able to stimulate the neuropsychomotor and social development of children, mothers mentioned: the child's limbs movement $(n=4)$, playing with the child $(n=5)$ and using rattle $(n=5)$, rolling toy $(n=4)$, musical toy $(n=5)$, ball $(n=$ $5)$, puzzle $(n=4)$, modeling clay $(n=3)$ and puppets $(n=4)$; in addition, show them the toys $(n=1)$, lay the child on the couch $(n=1)$, let the child stand $(n=1)$, take the child to early stimulation $(n=$ $2)$, teach them how to walk $(n=1)$ and tell children stories $(n=4)$.

\section{Category 3: Early stimulation in the development of the child with microcephaly}

In addition, it became evident that mothers believe that children's development improved from the time they were followed in the Early Stimulation Center:

It has already helped a lot. She was weaker. That part of her here [upper limbs] was very hard; but with the help here and at home, she already "arriba" [raises]. Now they [the Early Stimulation Center professionals] are working to see if she hardens the neck. (M1)

His growth and development is better now, but at first it wasn't, because I had not come to the polyclinic. After I've come, it's been getting better [...]. His legs were crossed, now they are uncrossing more, now he is sitting, slowly, but he is. He didn't move like this, he didn't turn on his side, now he does. He didn't crawl, and now he does. I think the service is great. (M2)

After I came here, she has started to walk, which she didn't before, she used to be afraid. (M3)

Development is improving. (M5)

It is noteworthy that one of the mothers interviewed reported that she did not notice that much improvement in her daughter, but she explains that this may be because they cannot take the child in all appointments, as this report shows:

I cannot say that she has improved a lot, no. She has improved a little. Because we do not come here as much. (M4)

The factor that most interferes with the mothers' attendance in early stimulation is the difficulty of getting transportation to the polyclinic, because some mothers live far from the institution:

Often we stay up to 11 hours waiting for the car. And that's already a big flu for her [child with microcephaly]. (M1)

The only thing that is bad is the transport, which is more difficult, because it is the mayor's responsibility [...]. And sometimes we cannot go, we miss it. (M2)

Because we lived far away, I was not getting transportation. Then I was missing a lot [of appointments], because I was affording it. I cannot afford to pay every time, because I haven't even received her benefit yet. (M4)

Among the reasons that encouraged the mothers to take their children to the program were the stimulation of child health improvement (one mother), the teaching of how to take care of the child (one mother), the improvement of the child's quality of life (one mother), and the help in their development (two mothers).

\section{Category 4: Service fragilities}

When performing an evaluation of the stimulation service, mothers reported that the negative point is the stimulation time with each professional, which is considered by them as insufficient to meet their children's needs. In addition, they emphasized the importance of continuing education for professionals, as shown in the following statements:

There are too many children, it's hard for her [the professional] to spend a lot of time with one child. Time is short. While you're taking off a child's clothes, two minutes already passed. (M4)

We're forgotten. The government has abandoned us, we have practically no help at all. There are only those professionals with 15 minutes available each, and I think 15 minutes for a child with the demands of our children, I think it's nothing. It needs to improve a lot. I think the time is very short [...]. I think these professionals should be going through recycling [updates]. To improve more and more and increase the time, because I think the time is very short. (M5)

\section{DISCUSSION}

It was found that the mothers of children with microcephaly associated with the zika virus participating in this study were young, farmers, with per capita income equivalent to one-quarter of the minimum wage in force at the time of the study ( $R \$ 937.00)$, and they had contact with mosquitoes all year round. These characteristics are similar to those found by studies investigating cases of microcephaly in Brazil, which showed that this anomaly occurred more frequently in families with this profile $\mathrm{e}^{(18-19)}$.

Income below a minimum wage is worrying, because the lower the purchasing power of families, the more difficult will be the access to health services, diagnosis, early treatment and rehabilitation, adequate housing conditions, quality food, acquisition of personal and environmental hygiene products and preventive measures against diseases ${ }^{(20)}$.

Another important factor is the information that women were constantly exposed to mosquitoes in their homes carrying several microorganisms, such as zika virus ${ }^{(21)}$, which can cause microcephaly. Considering this scenario, it can be seen that the child with the disease, exposed to this environment, also presents high risk of contracting infectious diseases transmitted by vectors, since they are already vulnerable due to the immaturity of their immune system ${ }^{(22)}$.

Children with microcephaly need specialized care to promote their development. To this end, it is necessary to elaborate public policies that aim to reduce the impact caused by an unfavorable social condition and guarantee the access of children and their families to health services in terms of reception, follow-up and referrals when necessary ${ }^{(23)}$.

In view of this vulnerability profile, Ordinance No. 58, dated June 3,2016 , was created, which provides for the access of the child with microcephaly to the Benefit of Continued Social Assistance (BPC). This benefit guarantees a minimum wage for people with disabilities and the elderly, who cannot afford to support themselves. To 
receive the $B P C$, the families must have a per capita income lower than $1 / 4$ of the minimum wage and will have to prove the deficiency through a medical report(24).

Even though the importance of BPC in the family context of the child with microcephaly is recognized, it was noticed in this study the report of a mother who reported that she had not yet received her daughter's benefit, and that this scenario prevented the child's attendance in the consultations of early stimulation. The difficulty of access to BPC was also reported in a study carried out with mothers of children with microcephaly who attended an outpatient clinic in Paraíba ${ }^{(18)}$.

The main barriers that these families face to access the benefit are the bureaucracy of the BPC request process, the schedule incompatibility between the National Social Security Institute (INSS) agencies and the free time of caregivers, besides income requirement, since $\mathrm{BPC}$ is only intended for people living in extreme poverty ${ }^{(18,25)}$. Besides these obstacles, a study evaluating the granting of BPC to children diagnosed with microcephaly showed that the demand for this benefit significantly increased in 2016, and that most of them were granted to the Northeast region ${ }^{(25)}$.

Concerning the age of the children investigated, four of them (80\%) were between 12 and 24 months old. This finding is because this study was carried out in an Early Stimulation Center that receives children from zero to 3 years old, since at this stage the brain is developing more quickly. Thus, intervening in this age group increases the effectiveness of actions performed by health professionals and promotes better motor, sensory, perceptive, proprioceptive, linguistic, cognitive, emotional and social development ${ }^{(26)}$.

It was observed that the mothers recognized the damages caused by microcephaly in the development of their children, and that the damages in the motor system were the most frequently mentioned. These reports are similar to those found in a study that evaluated the neuropsychomotor development of children with congenital zika virus infection, which showed that they had atypical motor performance and immaturity in suction, swallowing and breathing ${ }^{(12)}$.

Convulsive seizures were also reported by a mother. These are some of the characteristics that can be presented by children exposed to the syndrome of congenital infection by zika virus and may be manifested from the neonatal period-however epileptic seizures become more frequent after three months old ${ }^{(27)}$.

It is important to note that the fact that mothers know microcephaly and its damage to the development of children is relevant, because when they report not knowing their child's pathology adequately, accepting the diagnosis is slower, more difficult and painful(28).

It was noticed that the mothers could not define precisely what is early stimulation; however, they recognized and reported on the benefits it brought to the neuropsychomotor development of their children.

In addition, mothers were shown to recognize the importance of encouraging their children at home, and that they recognized some activities capable of promoting the child's stimulation. This finding is important because, in early stimulation programs in which active participation and the involvement of parents in interventions are allowed, the results are more evident. Thus, the relevance of extending interventions beyond the limits of the Early Stimulation Center ${ }^{(29)}$ is perceptible.
It was verified that all the women educated about this subject reported that the information on early stimulation was passed on only by professionals working in the polyclinic. However, all children, including those with microcephaly, should be accompanied by Primary Care through childcare consultations. The fact that the child and family are assisted by other services does not reduce or exclude the responsibility of the Family Health teams-rather, they should promote joint follow-up ${ }^{(30)}$.

This right to assistance in primary health care is part of the National Policy on Comprehensive Health Care for Children (PNAISC), created in 2015 with the objective of reducing child morbidity and mortality. It is divided into seven strategic axes responsible for regulating, guiding and qualifying actions and services provided to children in national territory ${ }^{(31)}$.

As the child with microcephaly has important neuropsychomotor deficits that can cause a series of disabilities, the specific axis for attending this audience corresponds to the sixth point of the policy, which refers to the attention to the child with disabilities or in specific situations and vulnerability. This axis seeks to guarantee a resolutive and inclusive health care for this public, by the articulation of intra and intersectoral strategies ${ }^{(31)}$. In this way, the importance and the responsibility of Primary Care for the child with microcephaly is evident, welcoming them since the puerperal consultation, performing the care to evaluate their development and referring them to appointments with professionals part of the Family Health Support Center (Nasf), centers for early stimulation and other services, when necessary ${ }^{(30)}$.

To strengthen and qualify the assistance provided to children with microcephaly, the Ministry of Health has launched protocols $^{(14,30)}$ aimed at guiding the actions of health professionals regarding the care of this public. Although the child with microcephaly should be followed up in Primary Care, as discussed above, no mother reported such follow-up.

A study carried out with caregivers of children with microcephaly seen at an early stimulation center in Ceará showed that the preparation of health teams to serve these families is still insufficient, which has resulted in fear and refusal of professionals to carry out childcare consultations or vaccination of children with microcephaly, in the difficulty to actually implement "active and humanized listening" in clinical practice and to carry out effective evaluations and interventions. In addition, the authors revealed the need for caregivers to be oriented regarding child daily care and first-aid behaviors capable of reversing intercurrences such as choking ${ }^{(32)}$.

Therefore, the importance of nursing in this context is emphasized, since it has the role of fully serving the population, seeking to act on the needs presented. Thus, the nurse has the responsibility to continuously monitor the growth and development of the child with microcephaly through nursing consultations, trying to elucidate doubts, guide the caregivers about the developmental progress of the child, their prognosis and the importance of early stimulation and strengthen the bond of the child-family binomial. For this, it is imperative that the nurse knows microcephaly and its repercussion in the neuropsychomotor development of the child ${ }^{(33)}$.

Thus, in addition to the publication of care manuals and protocols, it is important to carry out continuing education and sensitization of professionals, since quality care for children with disability must encompass biological, social, emotional and 
spiritual contexts. Therefore, it is necessary to involve technical knowledge, sensibility, empathy and integration of the multidisciplinary team ${ }^{(34)}$, which are strengthened in an effective permanent education.

A study carried out with parents of children with neurological disabilities showed the caregivers' dissatisfaction with the care given to their children, as they reported the need for more comprehensive care including psychosocial, economic and home care support networks ${ }^{(35)}$. This emphasizes the importance of intersectoral actions and the formation of care networks to children with microcephaly, since this will require the articulation of social assistance, health and education sectors so that the reception and full inclusion are guaranteed.

It was noticed that the mothers recognize the importance of early stimulation in the development of their children, being even able to report the advances occurred during consultations and the prospects of improvement of their clinical picture. In addition, based on the mothers' speeches, it was observed that they visualize the early stimulation service as a support capable of guiding them on the care of the child with microcephaly, of contributing to improve neuropsychomotor development and the child's quality of life.

These results are similar to those found in a study conducted with caregivers and therapists of children with language disorders that underwent early intervention, who reported advances in their language and motor development ${ }^{(36)}$.

Although early stimulation is an important service to provide advances in the development of children with microcephaly, it was possible to notice that some of the studies were not taken for all scheduled appointments. The main problem that interfered with their attendance was the unavailability of own transport, since the mothers did not have the financial condition to rent a car twice a week to take their child to the stimulation. Thus, they depend on the public service, mostly from the city hall, which does not always provide transportation.

The difficulty of access to the health care network and the financial structure of families were reported as two of the main challenges faced by caregivers of children with microcephaly followed up in early stimulation ${ }^{(16)}$.

Regarding the care provided in the Early Stimulation Center, it was noticed that the mothers listed as the main negative point the short stimulation time of the appointments with each professional-because, although they recognized that the professionals should also attend other children, they considered the time insufficient. Thus, one of the suggestions made by them to improve care was the increase in stimulation time and the need for permanent education for professionals.

This finding may be related to the fact that, during the period in which the study was performed, some professionals were on vacation and only the speech therapist and physiotherapist were present. Therefore, the total stimulation period was 30 minutes. Thus, as some mothers mentioned that the travel time to the polyclinic was much longer than the time of early stimulation, this might have contributed to their impression that time was insufficient.

\section{Limitation of the study}

As a limitation of the study, the reduced number of mothers who took part in the study and the fact that it was unicentric are highlighted. Thus, this study cannot be generalized, due to the specificity of the analyzed context and the restricted universe.

\section{Contributions to the field of nursing, health or public policy}

To provide quality care for children with microcephaly associated with zika virus and their relatives, it is necessary that nursing and health professionals in general know the peculiarities in the growth and development of this public.

Thus, the results presented here can be used to subsidize the planning of nursing care for the child with microcephaly so that it is holistic, capable of identifying the potentialities and peculiarities of each child, stimulating their development, providing them with a network service and being support for the families that face this diagnosis.

In addition, professionals will know the maternal perception of early stimulation, its main difficulties and knowledge about the subject. Thus, they will have subsidies to develop strategies of health education that aim to promote maternal knowledge regarding microcephaly and early stimulation and the qualification of the care provided to children.

\section{FINAL CONSIDERATIONS}

It was found that the mothers participating in this study recognized the damage caused by microcephaly and the importance of early stimulation for the neuropsychomotor development of children who have this malformation; despite this, they could not conceptualize it precisely. In addition, the participating mothers were able to identify some stimulation activities of the children at home and highlighted the main barriers to access to the Early Stimulation Center.

Finally, considering the mothers' speeches, it was noticed that the main source of information related to early stimulation were the professionals of the specialized service of the Early Stimulation Unit. Thus, it is necessary to carry out studies that investigate the perception of Primary Care professionals about the care of children with microcephaly, aiming to qualify the care provided to families and children in this condition.

\section{ACKNOWLEDGMENT}

To Coordenação de Aperfeiçoamento de Pessoal de Nível Superior (CAPES).

\section{REFERENCES}

1. Ministério da Saúde (BR). Secretaria de Atenção à Saúde. Protocolo de atenção à saúde e resposta à ocorrência de microcefalia relacionada à infecção pelo vírus zika [Internet]. Brasília: Ministério da Saúde; 2015 [cited 2018 Jan 20]. Available from: http://www.nutes.ufpe.br/indu/ pluginfile.php/12830/mod_resource/content/1/zika2.pdf 
2. Ministério da Saúde (BR). Protocolo de vigilância e resposta à ocorrência de microcefalia e/ou alterações do sistema nervoso central (SNC) [Internet]. Brasília: Ministério da Saúde; 2016 [cited 2018 Jan 20]. Available from: http://combateaedes.saude.gov.br/images/sala-desituacao/Microcefalia-Protocolo-de-vigilancia-e-resposta-10mar2016-18h.pdf

3. Dick GWA, Kitchen SF, Haddowa AJ. Zika virus (I) isolations and serological specificity. Trans R Soc Trop Med Hyg. 1952;46(5):509-20. doi: 10.1016/0035-9203(52)90042-4

4. Miranda-Filho DB, Martelli CMT, Ximenes RAA, Araújo TVB, Rocha MAW, Ramos RCF, et al. Initial description of the presumed congenital zika syndrome. Am J Public Health. 2016;106(4):598-600. doi: 10.2105/AJPH.2016.303115

5. Schuler-Faccini L, Ribeiro EM, Feitosa IML, Horovitz DDG, Cavalcanti DP, Pessoa A, et al. Possible association between zika virus infection and microcephaly: Brazil, 2015. MMWR Morb Mortal Wkly Rep. 2016;65(3):59-62. doi: 10.15585/mmwr.mm6503e2

6. Cugola FR, Fernandes IR, Russo FB, Freitas BC, Dias JLM, Guimarães KP, et al. The Brazilian zika virus strain causes birth defects in experimental models. Nature. 2016;534(7606):267-71. doi: 10.1038/nature18296

7. Sarno M, Aquino M, Pimentel K, Cabral R, Costa G, Bastos F, et al. Progressive lesions of central nervous system in microcephalic fetuses with suspected congenital Zika virus syndrome. Ultrasound Obstet Gynecol. 2017;50(6):717-22. doi: 10.1002/uog.17303

8. Calvet G, Aguiar RS, Melo ASO, Sampaio SU, Filippis I, Fabri A, et al. Detection and sequencing of zika virus from amniotic fluid of fetuses with microcephaly in Brazil: a case study. Lancet Infect Dis. 2016;16(6):653-60. doi: 10.1016/S1473-3099(16)00095-5

9. Besnard H, Lastère S, Teissier U, Cao-Lormeau VM, Musso D. Evidence of perinatal transmission of zika virus, French Polynesia, December 2013 and February 2014. Euro Surveill. 2014;19(13):1-4. doi: 10.2807/1560-7917.ES2014.19.13.20751

10. Abreu TT, Novais MCM, Guimarães ICB. Children with microcephaly associated with zika virus congenital infection: clinical and epidemiological characteristics in a tertiary hospital. Rev Ciênc Méd Biol. 2016;15(3):426-33. doi: 10.9771/cmbio.v15i3.18347

11. Feitosa IML, Schuler-Faccini L, Sanseverino MTV. Aspectos importantes da Síndrome da Zika Congênita para o pediatra e o neonatologista. Bol Cient Pediatr [Internet]. 2016 [cited 2018 Feb 23];5(3):75-9. Available from: http://www.sprs.com.br/sprs2013/bancoimg/170118173954 bcped_05_03_a02.pdf

12. Botelho ACG, Neri LV, Silva MQF, Lima TT, Santos KG, Cunha RMA, et al. Presumed congenital infection by zika virus: findings on psychomotor development - a case report. Rev Bras Saúde Matern Infant. 2016;16(Suppl. 1):S39-44. doi: 10.1590/1806-9304201600s100004

13. Ministério da Saúde (BR). Diretrizes de estimulação precoce: crianças de zero a 3 anos com atraso no desenvolvimento neuropsicomotor decorrente de microcefalia [Internet]. Brasília: Ministério da Saúde; 2016 [cited 2018 Feb 23]. Available from: http://portalsaude.saude.gov. br/images/pdf/2016/janeiro/13/Diretrizes-de-Estimulacao-Precoce.pdf

14. Ministério da Saúde (BR). Protocolo de atenção à saúde e resposta à ocorrência de microcefalia [Internet]. Brasília: Ministério da Saúde; 2016 [cited 2018 Feb 23]. Available from: http://combateaedes.saude.gov.br/images/sala-de-situacao/04-04_protocolo-SAS.pdf

15. Silva PLN, Soares ABA, Ferreira TN, Rocha RG. Maternal perception in terms of newborns with congenital malformations: a descriptive study. Online Braz J Nurs. 2015;14(2):190-6. doi: 10.17665/1676-4285.20155199

16. Meireles NFP, Duarte PHM, Mélo TM, Pereira HCB, Pinheiro YT, Silva RMC, et al. Familial and clinical sociodemographic profile of children with neurological dysfunction treated in the early intervention program. Arch Health Invest. 2017;6(10):495-9. doi: 10.21270/archi.v6i10.2256

17. Minayo MCS, Deslandes SF, Gomes R. Pesquisa social: teoria, método e criatividade. 34a ed. Petrópolis: Vozes; 2015.

18. Diniz Z. Zika virus and women. Cad Saúde Pública. 2016;32(5):e00046316. doi: 10.1590/0102-311X00046316

19. Marinho F, Araújo VEM, Porto DL, Ferreira HL, Coelho MRS, Lecca RCR, et al. Microcephaly in Brazil: prevalence and characterization of cases from the Information System on Live Births (Sinasc), 2000-2015. Epidemiol Serv Saúde. 2016;25(4):1-11. doi: 10.5123/ s1679-49742016000400004

20. Lucia CMD, Santos LLM, Anunciação PC, Silva BP, Franceschini SCC, Pinheiro-Sant'Ana HM. Socioeconomic profile and health conditions of children from two philanthropic child day care centers in the city of Viçosa, MG, Brazil. RASBRAN [Internet]. 2017 [cited 2018 Feb 24];8(2):311. Available from: https://rasbran.emnuvens.com.br/rasbran/article/view/655/168

21. Chouin-Carneiro T, Vega-Rua A, Vazeille M, Yebaquima A, Girod R, Goindin D, et al. Differential susceptibilities of Aedes aegypti and Aedes albopictus from the Americas to zika virus. PLoS NegI Trop Dis. 2016;10(3):e0004543. doi: 10.1371/journal.pntd.0004543

22. Escobar EM, Mellin AS, Tapia CEV, Piovesan RC, Noguchi ST. The use of recreational resources to assist the hospitalized child. Rev Ciênc Ext [Internet]. 2013 [cited 2018 Feb 25];9(2):106-19. Available from: http://ojs.unesp.br/index.php/revista_proex/article/view/828

23. Cabral CM, Nóbrega MEB, Leite PL, Souza MSF, Teixeira DCP, Cavalcante TS, et al. Clinical-epidemiological description of live births with microcephaly in the state of Sergipe, Brazil, 2015. Epidemiol Serv Saúde. 2017;26(2). doi: 10.5123/s1679-49742017000200002

24. Ministério de Desenvolvimento Social e Agrário (BR). Portaria n 58, de 3 de junho de 2016, Dispõe sobre ações articuladas das redes de Assistência Social e Previdência Social na atenção às crianças com microcefalia para o acesso ao Benefício de Prestação Continuada da Assistência Social - BPC [Internet]. Diário Oficial da União, 6 jun. 2016 [cited 2019 Mar 20]. Available from: http://www.lex.com.br/ legis_27147947_PORTARIA_N_58_DE_3_DE_JUNHO_DE_2016.aspx

25. Pereira EL, Bezerra JC, Brant JL, Araújo WN, Santos LMP. Profile of demand and Continuous Cash Benefits (BCP) granted to children diagnosed with microcephaly in Brazil. Ciênc Saúde Colet. 2017;22(11):3557-66. doi: 10.1590/1413-812320172211.22182017

26. United Nations International Children's Emergency Fund (Unicef). Early childhood development: the key to a full and productive life 
[Internet]. New York: Unicef; 2015 [cited 2018 Feb 25]. Available from: https://www.unicef.org/early-childhood-development

27. Eickmann SH, Carvalho MDCG, Ramos RCF, Rocha MÂW, Linden VVD, Silva PFS. Zika virus congenital syndrome. Cad Saúde Pública. 2016;32(7):e00047716. doi: 10.1590/0102-311X00047716

28. Pedroso CNLS, Félix MA. Parents' perception facing the diagnostic and physiotherapeutic approach for children with cerebral palsy. Rev Ciênc Saúde. 2014;7(2):61-70. doi: 10.15448/1983-652X.2014.2.16464

29. Franco V. Tornar-se pai/mãe de uma criança com transtornos graves do desenvolvimento. Educ Rev. 2016;59:35-48. doi: 10.1590/0104-4060.44689

30. Ministério da Saúde (BR). A estimulação precoce na Atenção Básica: guia para abordagem do desenvolvimento neuropsicomotor pelas equipes de Atenção Básica, Saúde da Família e Núcleo de Apoio à Saúde da Família (Nasf), no contexto da síndrome congênita por zika [Internet]. Brasília: Ministério da Saúde; 2016 [cited 2018 Feb 26]. Available from: http://189.28.128.100/dab/docs/publicacoes/geral/ estimulacao_precoce_ab.pdf

31. Ministério da Saúde (BR). Portaria no 1.130, de 5 de agosto de 2015. Institui a Política Nacional de Atenção Integral à Saúde da Criança (PNAISC) no âmbito do Sistema Único de Saúde (SUS) [Internet]. Diário Oficial da União, 06 ago. 2015 [cited 2019 Mar 20]. Available from: http://bvsms.saude.gov.br/bvs/saudelegis/gm/2015/prt1130_05_08_2015.html

32. Sá FE, Andrade MMG, Nogueira EMC, Lopes JSM, Silva APEP, Assis AMV. Parental needs in the care for children with zika virus-induced microcephaly. Rev Bras Promoç Saúde. 2017;30(4):1-10. doi: 10.5020/18061230.2017.6629

33. Veiga AS, Nunes CR, Andrade CCF. Assistência de enfermagem à criança com microcefalia. Múltiplos Acessos [Internet]. 2017 [cited 2018 Feb 26];2(2):116-28. Available from: http://multiplosacessos.com/multaccess/index.php/multaccess/article/download/40/38

34. Santos RS, Dias IMV. Refletindo sobre a malformação congênita. Rev Bras Enferm. 2005;58(5):592-6. doi: 10.1590/S0034-71672005000500017

35. Ansari NJR, Dhongade RK, Lad PS, Borade A, Yg S, Yadav V, et al. Study of parental perceptions on health \& social needs of children with neuro-developmental disability and its impact on the family. J Clin Diagn Res. 2016;10(12):SC16-20. doi: 10.7860/JCDR/2016/22538.9039

36. Pichini FS, Rodrigues NGS, Ambrós TMB, Souza APR. Family and therapist perception of child evolution in an interdisciplinary approach on early intervention. Rev CEFAC. 2016;18(1):55-66. doi: 10.1590/1982-021620161810915 